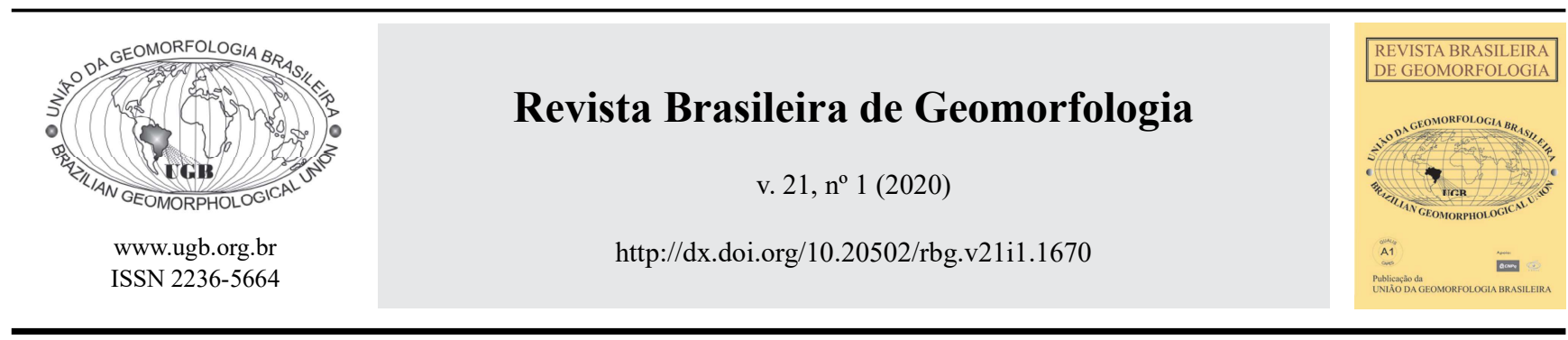

\title{
INDICADORES MORFOMÉTRICOS COMO SUPORTE PARAA CLASSIFICAÇÃO DE VOÇOROCAS EM SUB-BACIAS HIDROGRÁFICAS NO MUNICÍPIO DE CACEQUI, RS
}

\section{MORPHOMETRIC INDICATORS AS SUPPORT FOR THE CLASSIFICATION OF GULLIES IN HYDROGRAPHIC SUB-BASINS IN THE CACEQUI MUNICIPALITY, RS}

\author{
Tiéle Lopes Cabral \\ Departamento de Geociencias, Universidade Federal de Santa Maria \\ Av. Roraima $n^{\circ}$ 1000, Santa Maria, Rio Grande do Sul. CEP: 97105-900. Brasil \\ ORCID: 0000-0002-7048-6902 \\ E-mail: tielecabral@gmail.com
}

Andréa Valli Nummer

Departamento de Geociências, Universidade Federal de Santa Maria Av. Roraima $n^{\circ}$ 1000, Santa Maria, Rio Grande do Sul. CEP: 97105-900. Brasil ORCID: 0000-0001-9271-442X E-mail:a.nummer@gmail.com

Carlos Valdir de Meneses Bateira Faculdade de Letras, Universidade do Porto Via Panorâmica Edgar Cardoso, Porto. CEP:4150-564. Portugal ORCID: 0000-0002-5039-6053

E-mail: carlosbateira@gmail.com

\section{Informações sobre o Artigo}

Recebido (Received):

08/05/2019

Aceito (Accepted):

21/11/2019

\section{Palavras-chave:}

Classificação de Voçorocas; Subbacias Hidrográficas; Indicadores Morfométricos; Erosão.

\section{Keywords:}

Morphometric Indicators; Subbasins; Gullies Classification.

\begin{abstract}
Resumo:
Os indicadores morfométricos diretamente extraídos de incisões erosivas são essenciais para a classificação das diferentes formas de voçorocas, especialmente em áreas que possuem uma fragilidade ambiental atrelada a processos erosivos $\mathrm{e}$ tectônicos, como é o caso de sub-bacias hidrográficas localizadas no setor central do município de Cacequi, região sudoeste do Rio Grande do Sul. Com o propósito de classificar as voçorocas enquanto forma, foram realizadas análises estatísticas para definir os índices morfométricos a serem utilizados, tais como lineamentos estruturais, medidas de área, perímetro, comprimento, largura, volume, profundidade e Índice de Circularidade de cada incisão. Para a extração desses índices, foram usadas imagens de satélite WorldView-2 com 0,5m de resolução e o Modelo Digital de Elevação da plataforma AlosPalsar, com resolução de 12,5 metros, utilizando os Sistemas de Informações Geográficas para processamento dos dados, os quais possibilitaram a organização de um banco de dados contendo todas as informações. Todo esse processo favoreceu as análises, dando respaldo satisfatório ao entendimento do comportamento das feições erosivas, do relevo
\end{abstract}


e da litologia no contexto regional, evidenciando, assim, as principais formas de voçorocas: Linear, Bulbiforme, Ramificada, Irregular Mista, Retangular e Irregular Retangular. As voçorocas foram agrupadas em três conjuntos devido à semelhança dos dados morfométricos: no primeiro, estão as formas Lineares e Bulbiformes, com menores valores de área, profundidade e volume; no segundo, as formas Ramificada e Irregular Mista que possuem as maiores áreas, perímetros, amplitudes altimétricas e profundidades . No terceiro conjunto, estão as formas Retangular e Irregular Retangular com valores intermediários desses índices. Com base nos índices morfométricos, nos trabalhos de campo e na forma das voçorocas, foi possível sugerir um cenário de evolução do processo erosivo para a área de estudo. O processo de voçorocamento iniciaria pela forma Linear até alcançar a Retangular, considerada o estágio mais avançado. A Forma Irregular Mista poderia resultar da evolução de uma Linear ou Bulbiforme e evoluir para uma Irregular Retangular com o aumento do índice de Circularidade. A forma Retangular, considerada estabilizada, poderia reativar e evoluir para as formas Irregular Retangular e Irregular Mista.

\begin{abstract}
:
The morphometric indicators directly extracted from erosive incisions are essential for the classification of different forms of gullies, especially in areas that have an environmental fragility linked to erosive and tectonic processes, such as the case of sub-basins located in the central sector of the municipality of Cacequi, southwest of the state of Rio Grande do Sul, Brazil. In order to classify the gullies regarding their form, statistical analyses were performed to define the morphometric indexes to be used, such as structural lineaments, area measurements, perimeter, length, width, volume, depth and Circulation Index of each incision. For the extraction of these indexes, WorldView-2 satellite images with $0.5 \mathrm{~m}$ resolution and the Digital Elevation Model of the AlosPalsar platform were used, with a resolution of 0.5 meter, using the Geographic Information Systems for data processing, which made it possible to organize a large database containing all the information. All this process favored the analysis, giving satisfactory support to the understanding of the behavior of erosive features, relief and lithology in the regional context, thus evidencing the main forms of gullies: Linear, Bulbiform, Branched, Mixed Irregular, Rectangular and Irregular Rectangular. The gullies were grouped into three sets due to the similarity of the morphometric data: in the first are the Linear and Bulbiform forms, with smaller values of area, depth and volume; in the second, the Branched and Irregular Mixed forms that have the largest areas, perimeters, altimetric amplitudes and depths. In the third set are the Rectangular and Irregular Rectangular forms with intermediate values of these indexes. Based on morphometric indexes, fieldwork and gully form, it was possible to suggest a scenario of evolution of the erosion process for the study area. The gullying process supposedly starts by the Linear form, until it reaches the Rectangular form, considered the most advanced stage. The Mixed Irregular form could result from the evolution of a Linear or Bulbiform and evolve into a Rectangular Irregular with increasing Circularity Index. The Rectangular form, considered stabilized, could reactivate and evolve into Irregular Rectangular and Mixed Irregular forms.
\end{abstract}

\section{Introdução}

As análises morfométricas, com a preocupação de medir as formas de relevo através de processos sistemáticos e racionais, tiveram grande sucesso no final do século XIX, principalmente em pesquisas realizadas na Alemanha, na Áustria e na Suíça (CHRISTOFOLETTI, 2011). Esse tema expandiu-se e tomou maior repercussão no campo da análise tectônica através do trabalho de Filosofov (1960), sendo que, desde então, métodos para a construção e a validação de modelos morfométricos têm sido constantemente melhorados com o desenvolvimento de novas técnicas, como Gyozo Jordan (2003), Pánek (2004), Barbosa e Furrier (2011) e Jacques et. al (2014).
A representação morfométrica é frequentemente aplicada em pesquisas voltadas a análises e caracterização de bacias hidrográficas, amparada em técnicas e métodos de extração de índices a partir da própria configuração da drenagem, a exemplo dos trabalhos de Christofoletti (1969 e 2011), Tonello et al. (2006), Wilson et al. (2012) e Biswas (2016).

A análise morfométrica é também uma abordagem fundamental em estudos da formação e do desenvolvimento de vertentes, pois trata da medição e análise da configuração da superfície terrestre, fisionomia e dimensões de suas formas de relevo. Trabalhos como os de Castro e Carvalho (2009), Pissarra et al. (2010), 
Stipp et al. (2010), Mioto et al. (2014) e Passarella (2016) aplicam ponderações morfométricas à análise geomorfológica, com apoio de Modelos Digitais de Elevação (MDE), utilizando parâmetros, altimetria, lineamentos estruturais, solos, declividade do terreno, orientação e curvatura de vertentes, capacidade de transportes de sedimentos, inclinação longitudinal, fator de simetria topográfica transversal, assimetria da bacia de drenagem, amplitude altimétrica, índice de rugosidade, dissecação horizontal, além de combinar índices relacionados à rede de drenagem.

As técnicas morfométricas, empregadas na identificação e caracterização da superfície e análise do relevo, recebem cada vez mais contribuições científicas amparadas na coleta de dados advindos do Sensoriamento Remoto e, principalmente, na integração desses dados em ambiente SIG (Geoprocessamento), a exemplo dos trabalhos de Chien-Yuan Chen (2011), Cunha e Pinton (2013) e Fernandes (2014).

A extração de atributos morfométricos utiliza a análise de dados advindos do processamento digital de fotografias aéreas, imagens multissensoriais e de radar (MDE), análises estatísticas e geoestatísticas. De acordo com Zaidan e Xavier-da-Silva (2010), tais tecnologias demonstram ser uma ferramenta eficaz no que tange à precisão, à confiabilidade e à velocidade na geração de dados voltados à avaliação ambiental.

A região sudoeste do Rio Grande do Sul, em que se acha inserida a área de estudo, apresenta características ambientais marcantes em relação ao desenvolvimento de processos de dinâmica superficial. Os processos erosivos vêm sendo abordados em âmbito científico por meio de estudos cada vez mais detalhados do meio físico, destacando os seus atributos de maior influência.

Este artigo tem como objetivo apresentar os atributos morfométricos que foram aplicados para a análise e a classificação das formas de voçorocas presentes nas sub-bacias hidrográficas da Sanga Areal da Limeira, Sanga da Tapera, Sanga da Vaca Velha e Arroio Areal Grande, localizadas na porção central do município de Cacequi, sudoeste do Rio Grande do Sul. Foi utilizado, nas análises morfométricas, um conjunto de dados extraídos do comportamento superficial do relevo (hipsometria, declividade, orientação, comprimento, perfil e plano curvatura das vertentes, morfologia e lineamentos estruturais) e das voçorocas (área, perímetro, comprimento, largura, volume, profundidade e Índice de Circularidade).
Nesse contexto, a temática pesquisada surgiu devido à necessidade de análises em escalas de maior detalhe que permitam ampliar o conhecimento sobre a dinâmica atrelada aos processos de evolução das formas do relevo e a sua relação com o desenvolvimento de voçorocas localizadas em cabeceiras de drenagem, fato muito frequente em vários locais da região sudoeste do estado do Rio Grande do Sul.

\section{Área de estudo}

A área onde a pesquisa foi desenvolvida compreende um recorte localizado no setor central do município de Cacequi, situado entre 29 $48^{\prime} 21.12^{\prime \prime}$; 29 $9^{\circ} 57^{\prime} 06.80^{\prime \prime}$ de latitude sul e 54² $45^{\prime} 38.67^{\prime \prime} ; 54^{\circ} 29^{\prime} 45.44^{\prime \prime}$ de longitude oeste (Figura 1). Essa porção do município corresponde às superfícies das sub-bacias hidrográficas da Sanga Areal da Limeira, Sanga da Tapera, Sanga da Vaca Velha e Arroio Areal Grande, perfazendo uma área aproximada de $280 \mathrm{~km}^{2}$. Essa área faz parte da bacia hidrográfica do rio Ibicuí, responsável por drenar a porção central e oeste do Rio Grande do Sul, sendo considerada uma das principais bacias do Estado. Essa área foi escolhida por apresentar inúmeras voçorocas, algumas delas já estudadas por Robaina et al. (2002) e Cabral (2004), e por possuir características que a tornam representativa dos processos erosivos que ocorrem na porção oeste do Estado do Rio Grande do Sul.

Em termos de particularidades, as sub-bacias hidrográficas apresentam a montante aspectos de condição de drenagem encaixada. Os canais principais das sub-bacias Sanga Areal da Limeira e Sanga da Tapera mostram uma direção preferencial sudoeste-noroeste, com comprimentos respectivos de 21,5 e $12,5 \mathrm{~km}$. Na Sanga da Vaca Velha, o curso principal estende-se de Sul-Norte com um comprimento $17,2 \mathrm{~km}$ e o Arroio Areal Grande possui 21,2km de extensão, partindo de sudeste para noroeste até encontrar outro tributário da mesma sub-bacia, quando sofre um desvio de percurso no sentido de sul-norte. Todos esses cursos d'água desaguam no rio Ibicuí, que, por sua vez, mantém o sentido preferencial de Leste-Oeste. Esse fato expressa a condição consequente da drenagem tributária da margem esquerda nesse setor da bacia hidrográfica do rio Ibicuí.

Em termos geomorfológicos, a área de estudo está inserida em uma parcela da Depressão Central Gaúcha. Essa unidade corresponde à faixa que se estende de leste para oeste e em parte do sudoeste do estado do 
Rio Grande do Sul. Essa província Geomorfológica faz limite com o Planalto Meridional a nordeste e, a noroeste, com o Escudo Sul-Rio-Grandense a sudeste e, a leste, com a Planície Costeira (Ross, 1996). As características geomorfológicas da Depressão Central expressam a evolução do relevo constituído pelos materiais terrígenos da Bacia Sedimentar do Paraná.

Os processos de erosão acelerada que ocorrem nessa região correspondem às arenizações e aos voçorocamentos que atuam nas superfícies do relevo devido ao próprio contexto geológico/geomorfológico da área em questão, dando informações sobre a condição de fragilidade local/regional dessas áreas.

De acordo com Cabral (2004), ao longo da Depressão Central, há uma diferenciação espacial desses processos erosivos do centro para o oeste do Rio Grande do Sul, sendo mais significativa a presença de sulcos e voçorocas até o município de Cacequi, junto ao rio Santa Maria, e mais comum as arenizações em direção a oeste-sudoeste.

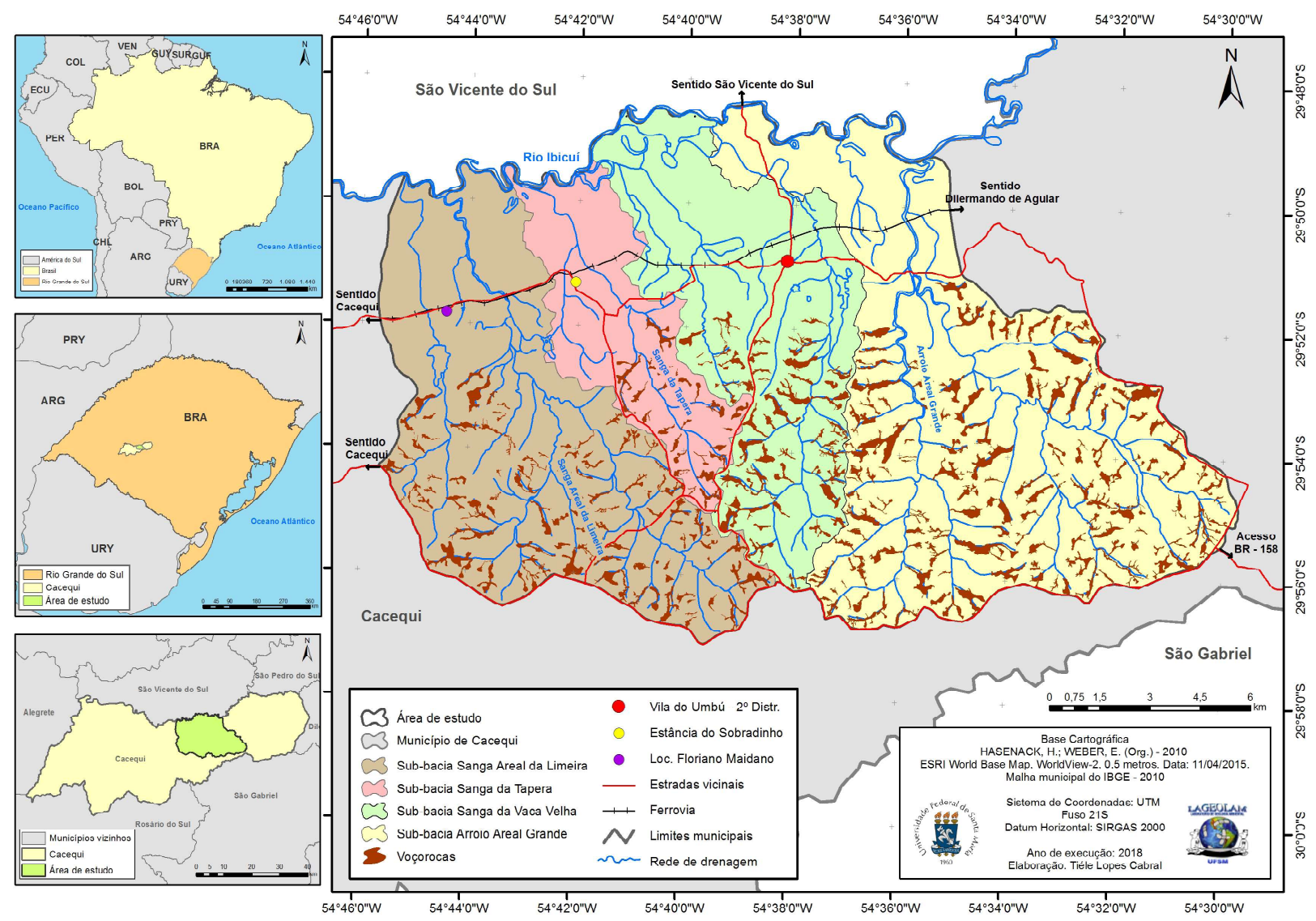

Figura 1-Localização geográfica da área de estudo no municipio de Cacequi, RS.

Morfologicamente, a área apresenta relevo com topografia ondulada em forma de colinas com baixas altitudes, 80 a $160 \mathrm{~m}$, e vertentes com rampas suaves, intercaladas por extensas planícies aluviais que se distribuem ao longo dos cursos d'água dos principais eixos de drenagem (CABRAL, 2004). Nessa área, as voçorocas ocorrem nas cabeceiras de drenagem das sub-bacias hidrográficas, estando presente ou não a vegetação.

As rochas sedimentares encontradas na área de estudo pertencem à Bacia do Paraná, que está loca- lizada no centro leste da América do Sul, sobre um embasamento cristalino (Plataforma Sul Americana), constituído por rochas metamórficas e ígneas. A forma da Bacia é alongada para NE e está relacionada à reativação de antigas estruturas tectônicas do embasamento que promoveram, localmente, uma maior subsidência nas direções NNE, NE e NW.

As incisões erosivas ocorrem sobre as rochas sedimentares da Formação Pirambóia (Grupo Passa Dois), conforme mapeamento geológico da Companhia 
de Pesquisa de Recursos Minerais - CPRM (2005). As rochas correspondem a arenitos médios a finos com geometria lenticular bem desenvolvida. São moderadamente selecionados, avermelhados, com estratificações cruzadas de grande porte que remetem a uma origem continental eólica com intercalações fluviais (Figura 2). Essas rochas ocorrem em topos de colinas e fundos de vales.

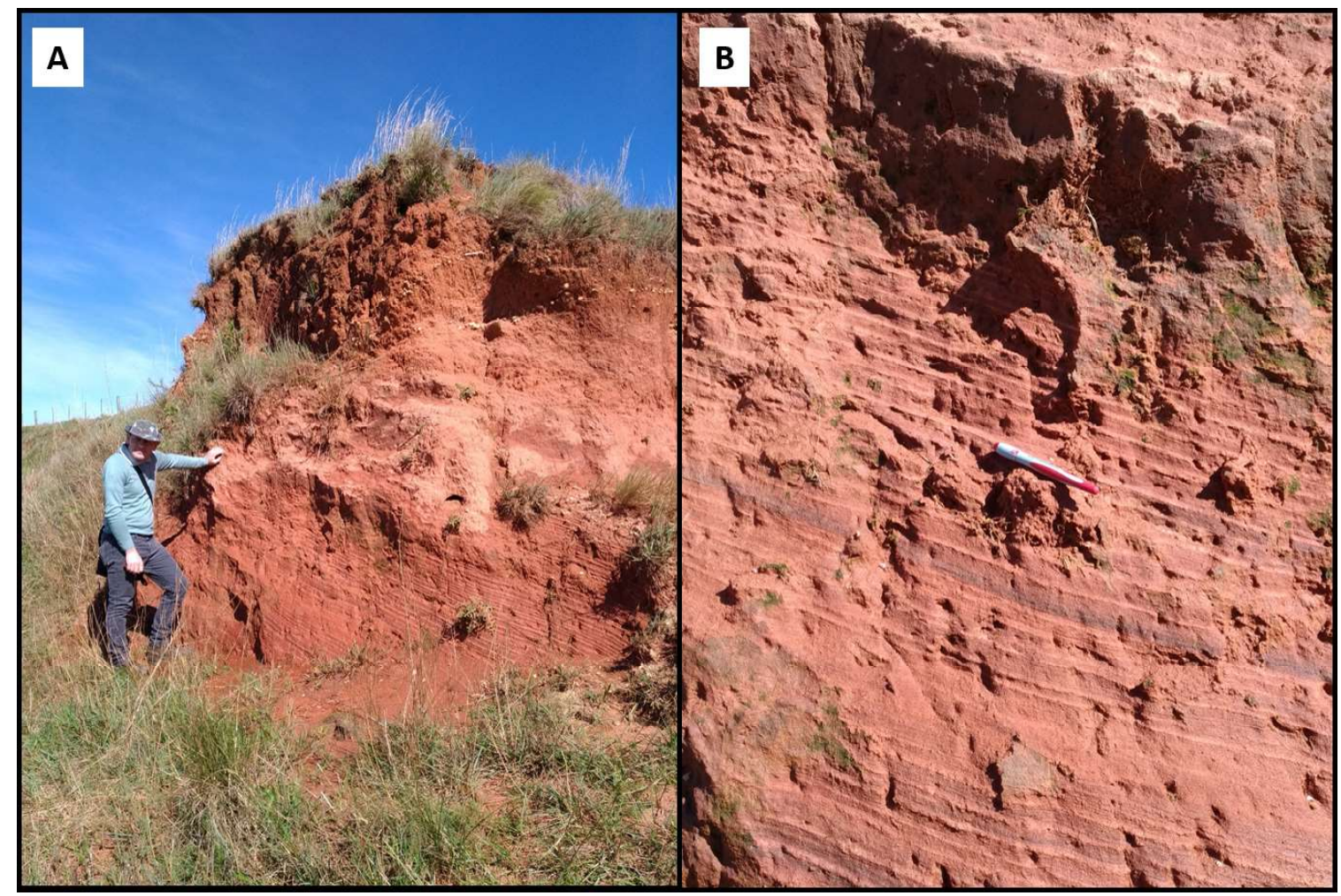

Figura 2 - Arenito de coloração avermelhada (A); detalhe da estratificação cruzada (B). Voçoroca nº 195. Fonte: Trabalho de campo (2018), fotografia de Tiéle Lopes Cabral.

Também na Formação Pirambóia, ocorrem os depósitos aluviais relacionados a barreiras holocênicas compostas por areias grossas a finas, cascalhos e sedimentos síltico-argilosos, em calhas de rio e planícies de inundação. Neste estudo, não foi realizado um mapeamento geológico de detalhe e, portanto, em relação à litologia, não foram consideradas as diferenças de fácies dentro da Formação Pirambóia.

Em relação à tectônica frágil (fraturas e falhas representadas pelos lineamentos estruturais), Zalán et al. (1990) demonstraram que os trends NW e NE ocorrem em toda a Bacia do Paraná, tendo também confirmado a existência de um terceiro grupo de lineamentos com orientação E-W. As orientações mais importantes são as NW-SE e NE-SW, que representam zonas de fraqueza antigas, recorrentemente reativadas durante a evolução da bacia.

O sistema NE (mais jovem) desenvolveu-se no Proterozóico Inferior a Superior e com importantes reativações no Brasiliano. As zonas de falhas NE, segundo Zalán et al. (1990), são constituídas ou por uma falha larga ou por uma zona de falha retilínea. No Mesozóico, as estruturas NE permitiram a ascensão dos magmas toleíticos da Formação Serra Geral. As reativações mais recentes são marcadas por grandes lineamentos no pacote vulcânico da bacia do Paraná e pelo condicionamento da sedimentação Cenozóica.

As estruturas EW são registradas no Mesozóico, como estruturas de natureza rúptil, acarretando o desenvolvimento de drenagens retilíneas e paralelas, marcadas pelo Rio Jacuí e Camaquã - Sistema de fratura Porto Alegre -Alinhamento do Camaquã e Rio Uruguai (Asmus, 1978) e Arroio Basílio - Lineamento Jaguarão (Costa e Ramgrab, 1989).

Os movimentos das zonas de falha NE e NW tiveram componentes horizontais e verticais e influenciaram a sedimentação das várias unidades estratigráficas da Bacia do Paraná. 
$\mathrm{Na}$ área, predominam campos de pradarias, ocupando regiões compostas por solos arenosos com ou sem floresta de galeria (MARCHIORI, 1995), local onde é comum a criação extensiva do gado, ou seja, a intervenção humana nesses ambientes dá-se pelo uso predominante da pecuária e das culturas agrícolas diversificadas como a orizicultura irrigada, que é praticada nas planícies de inundação e terraços dos rios de maior ordem, silvicultura e soja.

O clima característico dessa área é Subtropical medianamente úmido com variações das temperaturas médias, possui uma área com maior influência dos sistemas polares e tropicais continentais, porém com interferência crescente dos sistemas tropicais marítimos, influenciando até mesmo no relevo da Depressão Central. Os sistemas frontais são responsáveis pela maior parte das precipitações, as chuvas oscilam entre 1500-1700mm anuais, distribuídas entre 90 a 110 dias. A temperatura média anual varia entre $17^{\circ} \mathrm{C}$ e $20^{\circ} \mathrm{C}$, a temperatura do mês mais frio oscila entre $11^{\circ} \mathrm{C}$ e $14^{\circ} \mathrm{C}$ e a temperatura média do mês mais quente varia entre 23-26 ${ }^{\circ} \mathrm{C}$ (ROSSATO, 2011).

As voçorocas ocorrem em terrenos com declividades acima de $5 \%$, correspondentes ao topo de colinas e vales entalhados e não entalhados, presentes em vertentes com bases convexas, onde se verificam encostas com maiores declividades, pequenos comprimentos e maiores altitudes. Tais configurações favorecem o aumento da velocidade dos escoamentos, com maior dissecação e, consequentemente, maior concentração de voçorocas.

Dessa forma, o quadro natural da área mantém um padrão de comportamento em relação as suas características de relevo, solo e geologia, influenciando a distribuição e a evolução das voçorocas que ocorrem nessa região.

\section{Materiais e métodos}

Para o presente estudo, foi realizado um levantamento bibliográfico sobre classificação de voçorocas e índices morfométricos, bem como sobre a área de estudo a partir de discussões e mapeamentos já existentes, como o Projeto RADAMBRASIL (1973), além de estudos mais específicos voltados à erosão e à arenização no oeste sul rio-grandense, desenvolvidos por Suertegaray et al. (2001), Robaina et. al (2002) Robaina e Trentin (2004) e Cabral (2004).
Para a elaboração da base cartográfica, foram utilizadas as informações hidrográficas, a localização de estradas e topográficas (curvas de nível e pontos cotados) contidas no banco de dados topográficos do Rio Grande do Sul, na escala de 1:50.000 (HASENACK e WEBER, 2010) e malhas cartográficas dos municípios da Federação do Instituto Brasileiro de Geografia e Estatística (IBGE, 2010).

Para a extração dos índices morfométricos, empregaram-se, como base cartográfica, as Imagens de radar do Modelo Digital de Elevação (MDE) AlosPalsar - Global Radar Imagery (2006-2011) com resolução de 12,5m e imagens de satélite WorldView-2, disponibilizadas pelo ESRI World Base Map, de abril de 2015, com a resolução espacial de $0.5 \mathrm{~m}$ e, para o processamento desses materiais, foi utilizado o Sistema de informação Geográfica (SIG). Foram realizados trabalhos de campo utilizando GPS (Sistema de Posicionamento Global), bússola e câmera fotográfica digital para identificação e avaliação das voçorocas. Os trabalhos de campo auxiliaram no processo de classificação das diferentes formas de voçorocas.

Foram identificadas 298 voçorocas distribuídas dentro do perímetro da área de estudo. Essas incisões foram mapeadas/espacializadas através de um traçado (polígono) do seu entorno, utilizando o programa ArcGis 10.4, posteriormente, possibilitaram a criação de um conjunto de dados morfométricos extraídos diretamente dos limites das voçorocas.

A fim de eliminar a subjetividade na caracterização da forma das voçorocas, foram elaborados cálculos para a obtenção dos seguintes índices morfométricos, com base na metodologia utilizada por Christofoletti (2011) para a análise de bacias hidrográficas:

a) Área e Perímetro: calculados diretamente no Calculate Geometry do ArcGis; b) Largura: calculada através da criação de diversas linhas perpendiculares ao maior comprimento lateral ao longo de toda a área da voçoroca, com equidistâncias de 50 metros; c) Comprimento: levou-se em conta o maior percurso entre a parte a jusante e a cabeceira da voçoroca; d) Profundidade e Volume de material erodido, foram originados a partir do Modelo Digital de Elevação e, e) Índice de Circularidade, em que os valores próximos de 1,0 indicam fragmentos que tendem à forma arredondada e os valores que se distanciam de 1,0 apontam que os fragmentos aproximam-se de uma forma alongada, ou 
seja, a finalidade do índice de circularidade é comparar a forma da voçoroca, com a de um círculo, aplicando a equação do índice de circularidade (Ic):

$$
\text { Ic }=\frac{A}{A C}
$$

Desse modo, o Índice de Circularidade é resultado da divisão entre a área da voçoroca (A) pela área da figura geométrica (Ac), representada pelo círculo, com valores que variam de 0 a 1,0 .

Vale destacar que a classificação da forma das voçorocas baseou-se, inicialmente, em estudos de Bigarella e Mazuchowski (1985) e em Vieira (2008), sendo, posteriormente, adaptada à área de pesquisa

A correlação entre os indicadores morfométricos das voçorocas demandou o emprego de análises estatísticas, sendo aplicado o método da correlação linear simples. Tais dados foram analisados isoladamente e em conjunto, sempre procurando entender como cada indicador comporta-se frente às diferentes formas de voçorocas.

A identificação dos principais lineamentos estruturais baseou-se no mapa geológico do Estado do Rio Grande do Sul, na escala de 1:750.000, elaborado pela Companhia de Pesquisa de Recursos Minerais - CPRM (2006), e em pesquisa de Trentin et al. (2015), bem como nas avaliações realizadas nos trabalhos de campo. A identificação espacial das litologias na área serviu de base para a análise geomorfológica, permitindo relacionar com os demais fatores condicionantes aos processos superficiais que ocorrem na região.

Para a extração dos lineamentos estruturais, considerou-se o conceito de lineamento de Strieder e Amaro (1997). Foram identificados os lineamentos Tipo 2 que são os segmentos retilíneos de drenagem e representam zonas de fratura ou qualquer outro tipo de descontinuidade da rocha, onde houve percolação de água superficial e, portanto, maior propensão à alteração intempérica.

A identificação e a caracterização das estruturas foram realizadas por meio da extração manual dos lineamentos em imagens de satélite WorldView-2, com posterior conferência em campo. Trabalhou-se com duas escalas de análise: uma regional, para a todas as sub-bacias, e outra de detalhe, para as voçorocas. Os dados das direções dos lineamentos foram rebatidos para o primeiro e segundo quadrantes (sentido horário) e, com o auxílio do Software StereoNet, foram elaborados os diagramas de rosetas, com o objetivo de auxiliar na identificação e separação das famílias de descontinuidades.

A análise morfométrica e dos lineamentos serviu como subsídio para caracterizar, classificar e compreender o comportamento das voçorocas na área estudada.

\section{Resultados}

Foram identificadas 298 voçorocas, que compreendem uma área total de $22,5 \mathrm{~km}^{2}$, representando $8 \%$ da área de estudo. A sub-bacia hidrográfica do Arroio Areal Grande mantém a maior concentração de voçorocas, 134 unidades, seguida pela sub-bacia Sanga Areal da Limeira com 98 incisões. As menores sub-bacias Sanga da Vaca Velha e Sanga da Tapera, possuem, respectivamente, 44 e 22 incisões dentro do seu perímetro.

A classificação das voçorocas por forma seguiu, inicialmente, um conhecimento direcionado às particularidades da área de estudo, calcada na análise qualitativa, levando em consideração a categorização visual do comportamento e distribuição das diferentes incisões, além de trabalhos já existentes sobre a temática (Bigarella e Mazuchowski, 1985 e Vieira, 2008). Posteriormente, atrelando a essa análise, considerou-se os dados quantitativos voltados às incisões, trazendo-se à tona uma nova classificação, sendo definidas seis formas de voçorocas conforme a Figura 3.

As formas das voçorocas definidas para a área de estudo são:

a) Linear - resultante, geralmente, de um fluxo superficial concentrado, mantém-se em uma única direção estrutural, pequenos valores de largura (18 a $107 \mathrm{~m}) \mathrm{e}$ baixo Índice de Circularidade (valor médio de 0,165 );

b) Bulbiforme - evolui a partir da linear, com uma abertura circular de fluxo em direção à parte superior da encosta. Mantém-se estreita no eixo principal e aumenta a sua largura no topo. Apresenta baixo índice de circularidade com valor médio de 0,168 ;

c) Ramificada - caracterizada pela ocorrência de vários canais de drenagem superficiais em diferentes direções de fluxos e estruturas. Possui valores baixos de largura (média de 55,9m) e índice de circularidade (média de 0,086); 
Linear

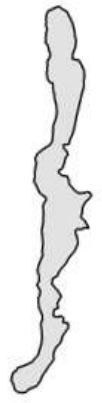

Bulbiforme

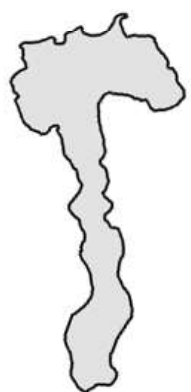

Ramificada

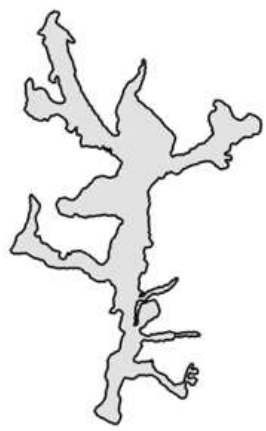

Irregular Retangular

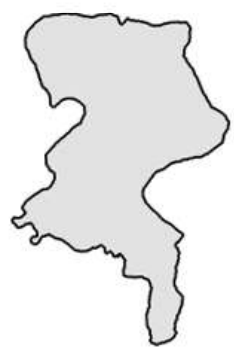

Irregular Mista

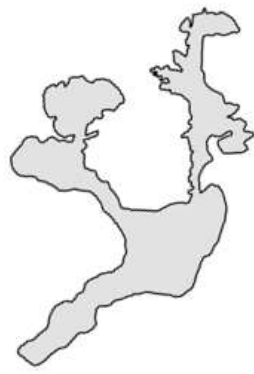

Retangular

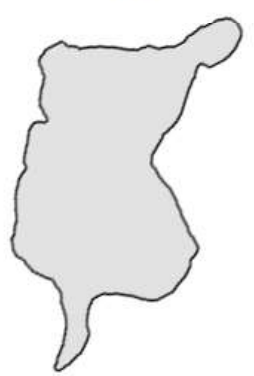

Figura 3 - Principais formas de voçorocas encontradas na área de estudo.

d) Irregular Mista - mantém uma abertura mais larga ao longo da sua extensão com ramos e/ou bulbos conectados no topo. Apresenta várias orientações dos fluxos superficiais concentrados dentro dela.

e) Retangular - configura-se como o estágio avançado de evolução da voçoroca de fundo chato, podendo reativar e passar para a classe irregular retangular, está relacionada a uma fase de estabilização. Mantém o Índice de Circularidade no mais alto patamar (média de 0,362) e valores de largura elevados (média de 106,64m).

f) Irregular retangular - apresenta alto índice de circularidade (média de 0,192), com valor elevado de largura (média de 75,53m), diferencia-se da retangular pelo avanço da forma, mantendo abertura em diferentes direções.

Com base nessa classificação, foram identificadas 22 voçorocas Lineares, 38 Bulbiformes, 120 Ramificadas, 24 Irregulares Mistas, 21 Retangulares e 73 Irregulares Retangulares. As formas Ramificada e Irregular Retangular são as que mais se destacam em termos de ocorrência com $40,2 \%$ e $24,4 \%$, respectivamente, distribuídas ao longo de todas as sub-bacias hidrográficas na área de estudo. A Figura 4 mostra exemplos das formas de voçorocas definidas para a área de estudo.

As informações diretamente extraídas do limite das voçorocas correspondem às medidas de área, perímetro, índice de circularidade, largura e comprimento de cada incisão (Tabela 1), já os dados relativos ao volume e profundidade foram extraídos do MDE. Esses índices deram suporte ao agrupamento de voçorocas com características semelhantes e, assim, foi possível caracterizar com uma maior precisão as formas de voçorocas definidas.

No quesito perímetro, conforme Figura 5-B, também concentram-se com maiores valores as formas Ramificada (3.672m) e Irregular Mista (3.275m), seguida dos valores intermediários representados pelas formas Bulbiforme (1.978m) e Irregular Retangular $(2.057 \mathrm{~m})$, restando, com os menores valores de perímetro, as formas Linear (1.397m) e Retangular (1.436m).

O Índice de Circularidade (IC) é um indicador que representa a abertura de uma voçoroca, permitindo separar as formas Ramificada $(0,08)$ e Irregular Mista $(0,13)$ com os menores valores; com valores intermediários, há as Lineares $(0,16)$ e Bulbiformes $(0,16)$. Restando as formas Retangular $(0,36)$ e Irregular Retangular $(0,19)$, que compreendem os maiores índices (Figura 6-A), já que se encontram em uma fase avançada de evolução, com maiores larguras e, dessa forma, mais abertas, integrando-se à paisagem. 

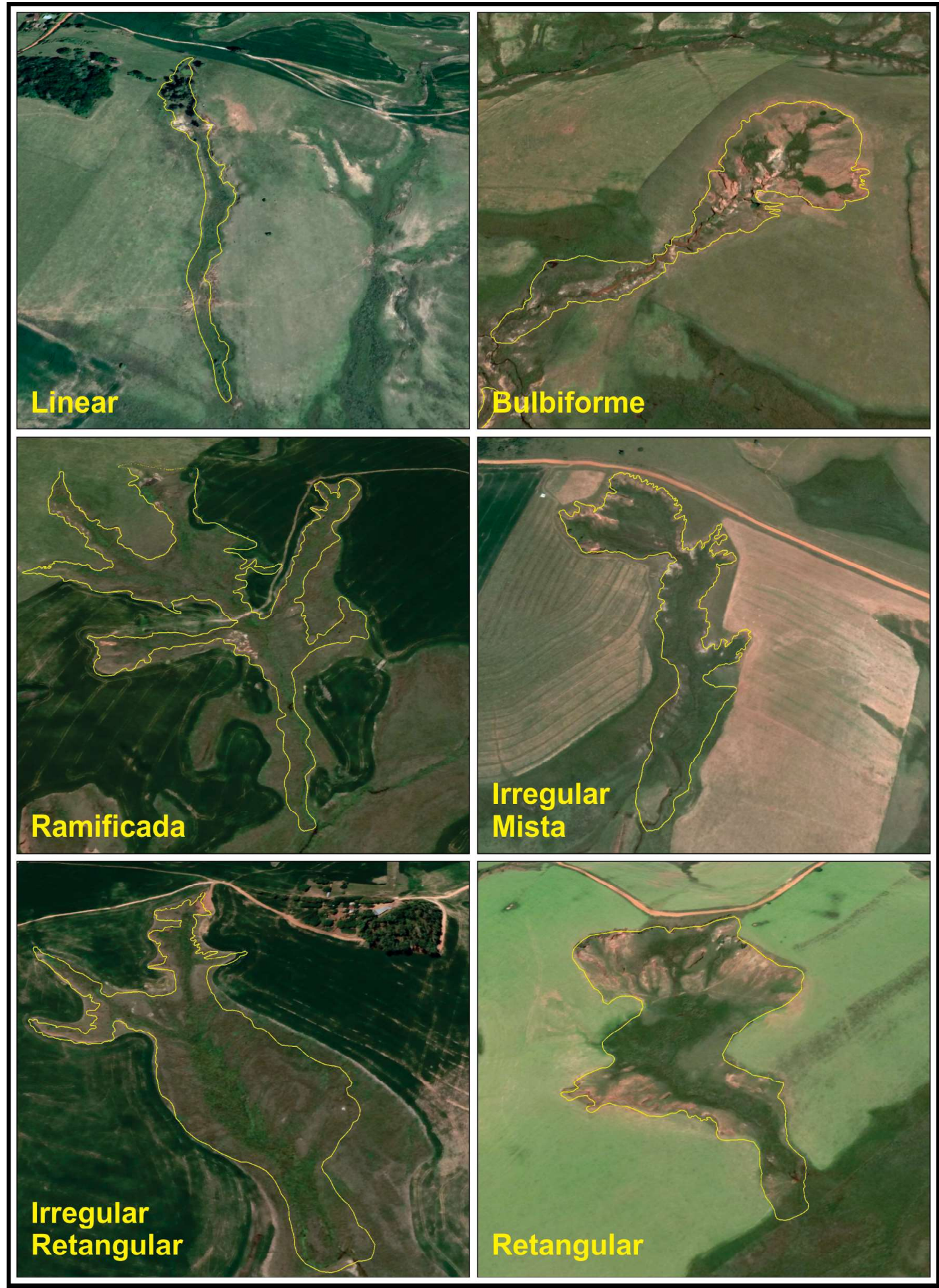

Figura 4 - Formas das voçorocas definidas para a área de estudo. Imagem: Google Earth 08 de agosto 2017, visão oblíqua.

No que tange ao comprimento das voçorocas (Figura 6-B), a maior extensão encontrada em algumas delas pode ser explicada pela existência de um fluxo principal (para cada incisão), o qual tende a provocar erosão remontante, seguindo uma orientação principal. Os maiores comprimentos de voçorocas encontram-se nas formas Ramificada $(935,04 \mathrm{~m}) \mathrm{e}$ Irregular Mista $(998,99 \mathrm{~m})$, os valores intermediários referem-se às formas Bulbiforme $(653,68 \mathrm{~m}) \mathrm{e}$ Irregular Retangular $(675,13)$. Os menores comprimentos atrelam-se às formas Retangular $(548,97 \mathrm{~m})$ e Linear $(579,04 \mathrm{~m})$. 
Tabela 1: Características métricas das voçorocas na área de estudo - Distribuição por Formas.Entre os valores apresentados, nota-se que as maiores voçorocas em termos de área concentram-se nas formas Ramificada e Irregular Mista, com respectivos valores de 90.055 e $110.756 \mathrm{~m}^{2}$. Vale destacar que essas formas apresentam ramificações distribuídas nos setores mais elevados das vertentes. Na Figura 5-A, pode-se observar que as formas Linear e Bulbiforme mantêm os valores mais baixos em relação à área $\left(29.497\right.$ e $\left.53.552 \mathrm{~m}^{2}\right)$. Mantendo-se em um patamar intermediário de área, encontram-se as formas Retangular e Irregular Retangular (68.214 e 67.228m²).

\begin{tabular}{|c|c|c|c|c|c|c|c|c|}
\hline Formas & $\begin{array}{c}\mathrm{N}^{\mathbf{o}} \\
\text { voçorocas }\end{array}$ & $\mathbf{A}\left(\mathbf{m}^{2}\right)$ & $\mathbf{P}(\mathbf{m})$ & IC & $\mathbf{L}(\mathbf{m})$ & Pf (m) & Cp (m) & Vol. $\left(\mathbf{m}^{3}\right)$ \\
\hline Linear & 22 & $29.497,08$ & 1397,75 & 0,16 & 45,27 & 2,09 & 579,04 & $62.810,97$ \\
\hline Bulbiforme & 38 & $53.552,39$ & 1978,01 & 0,16 & 67,86 & 3,27 & 653,68 & $174.411,11$ \\
\hline Ramificada & 120 & $90.055,73$ & 3672,38 & 0,08 & 55,92 & 3,40 & 925,04 & $299.112,99$ \\
\hline Irregular Mista & 24 & 110756,11 & 3275,92 & 0,13 & 84,32 & 3,96 & 998,99 & $412.319,53$ \\
\hline Retangular & 21 & $68.214,56$ & 1436,74 & 0,36 & 106,64 & 3,40 & 548,97 & $270.722,12$ \\
\hline Irregular Retangular & 73 & $67.228,67$ & 2057,00 & 0,19 & 75,53 & 3,25 & 675,13 & $224.660,72$ \\
\hline
\end{tabular}

Vocos: Voçorocas; A: Área; P: Perímetro; IC: Índice de Circularidade; L: Largura; Pf: Profundidade; Cp: Comprimento; Vol.: Volume. Min: Mínima; Max: Máxima; Med: Média.

Organização: Cabral, 2018.
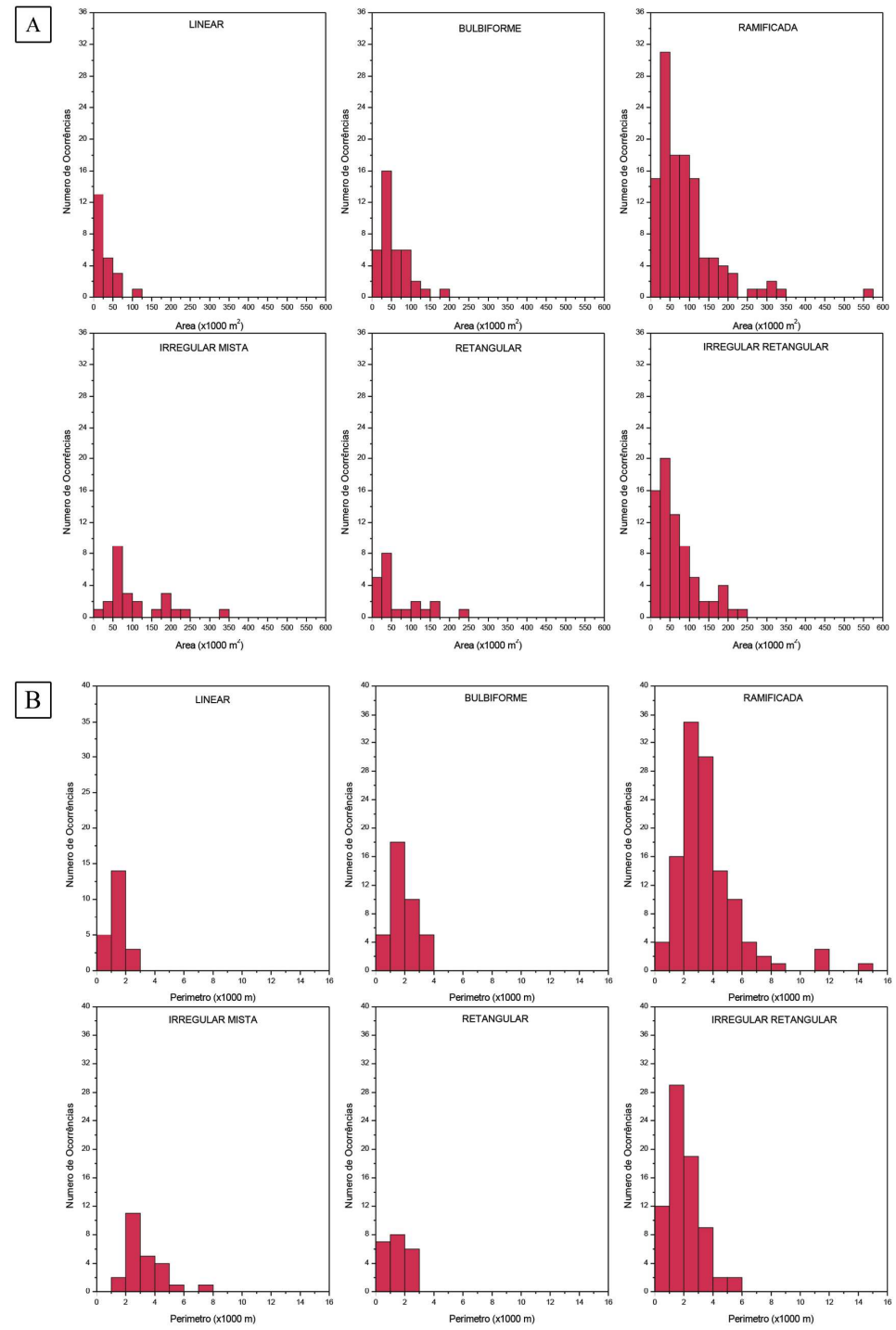

Figura 5 - Ocorrência de voçorocas em relação a suas modalidades versus Área (a) e relação com o Perímetro (b). 
a)
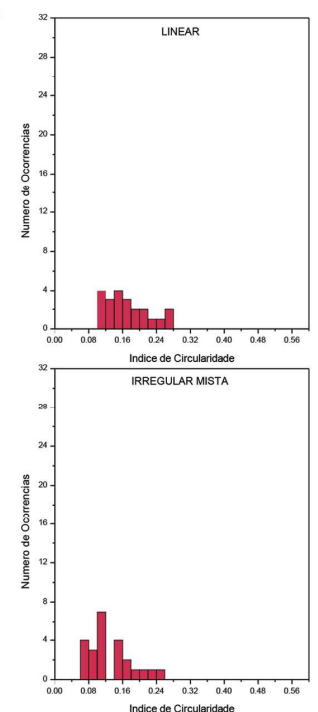

b)
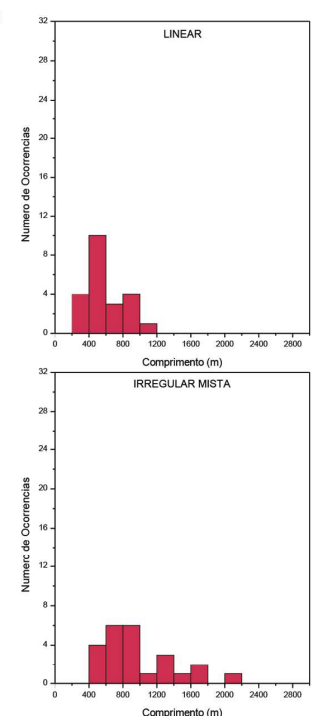
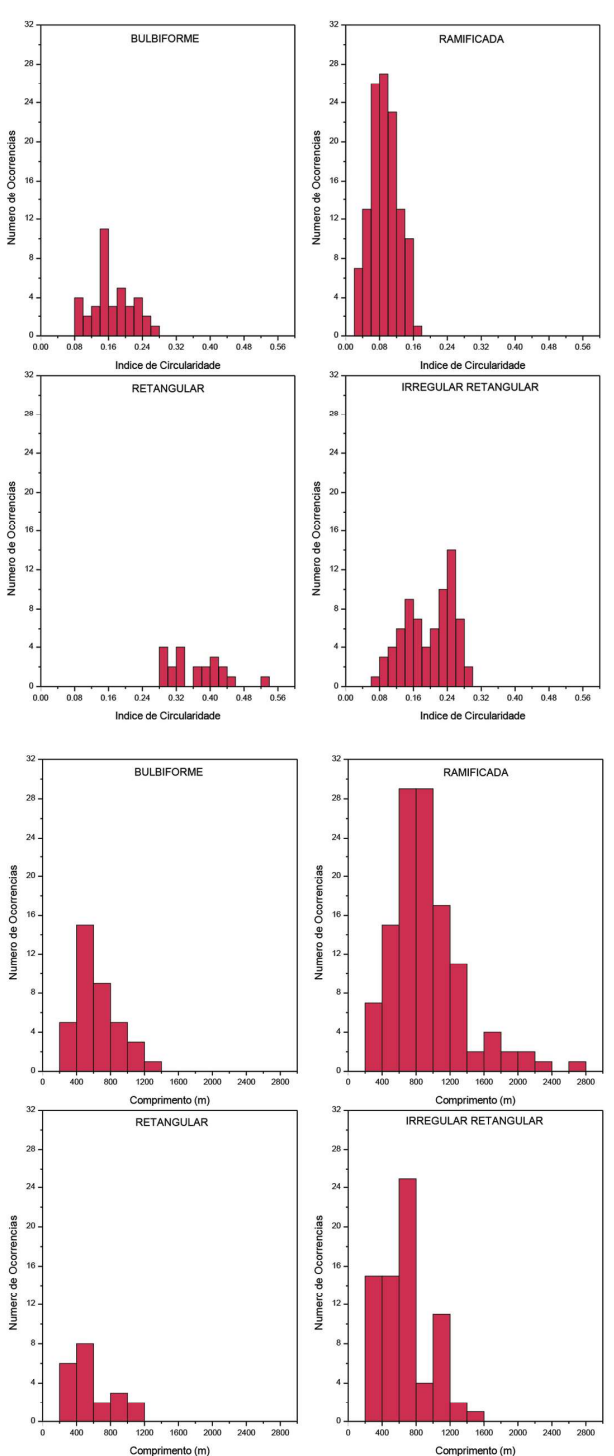

Figura 6 - Ocorrência de voçorocas em relação as suas modalidades versus Índices de Circularidade (A) e Comprimento (B).

As maiores profundidades verificadas correspondem às voçorocas Irregular Mista $(3,96 \mathrm{~m})$, Ramificada $(3,40 \mathrm{~m})$ e Retangular $(3,40 \mathrm{~m})$. Isso é um indício da presença de falhas ou fraturas na região, fato que condiciona o entalhe delas. De acordo com a Figura 7-A, os menores valores de profundidade enquadram-se nas formas Linear (2,09m), Irregular Retangular (3,25m) e Bulbiforme (3,27m).

As voçorocas Linear e Bulbiforme apresentam volume erodido médio de $62.810,97$ e $174.411,11 \mathrm{~m}^{3}$, representando as menores taxas de material erodido (Figura 7-B), seguidas pelas formas Retangular $\left(270.722,12 \mathrm{~m}^{3}\right)$ e Irregular Retangular $\left(224.660,72 \mathrm{~m}^{3}\right)$, mantendo valores intermediários. Os maiores valores de material erodido estão nas formas Ramificada $\left(299.112,99 \mathrm{~m}^{3}\right)$ e Irregular Mista $\left(412.319,53 \mathrm{~m}^{3}\right)$.

A largura é um indicador morfométrico que auxilia no entendimento acerca do grau de evolução e desenvolvimento de uma voçoroca, onde as formas Linear $(45,27 \mathrm{~m})$, Ramificada $(55,92 \mathrm{~m})$ e Bulbiforme $(67,86)$ apresentam as menores larguras, denotando maior concentração de fluxo superficial nessas formas. Já as formas Irregular Mista $(84,32 \mathrm{~m})$, Retangular $(106,64 \mathrm{~m})$ e Irregular Retangular $(75,53 \mathrm{~m})$ mantêm as maiores larguras de voçorocas (Figura 8). 

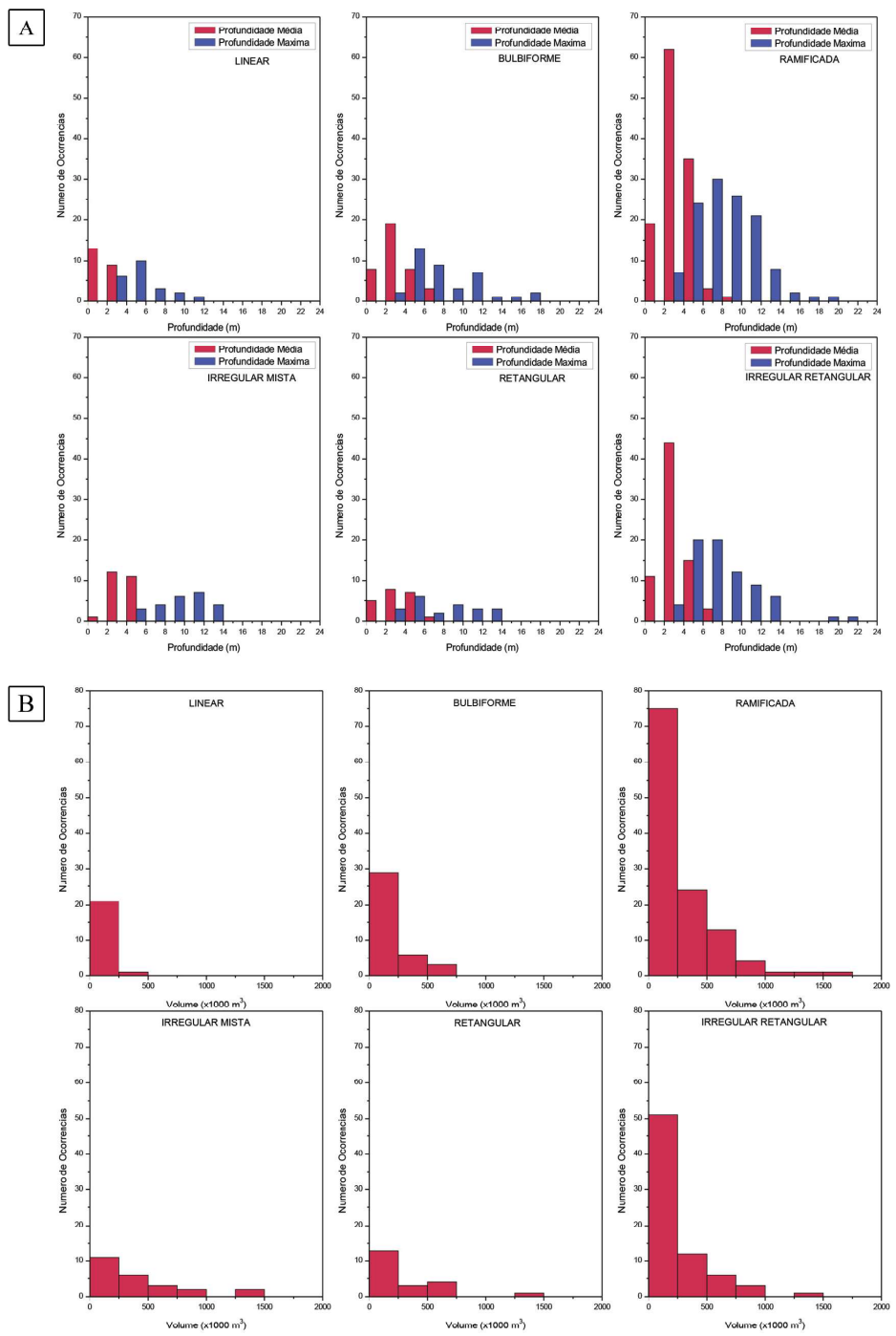

Figura 7 - Ocorrência de voçorocas em relação as suas modalidades versus Profundidade (a) e Volume (b).

As incisões com larguras superiores a $70 \mathrm{~m}$ são características de voçorocas que ocorrem em superfície mais plana e/ou com menor resistência do solo e/ou pela existência de fluxos oriundos de diferentes direções que convergem para um ponto único, controlados pela forma do plano de curvatura das vertentes e também pelas estruturas geológicas .

Em voçorocas como as Ramificadas e Irregular Mista os escoamentos concentrados convergem em diferentes direções, influenciadas pelos lineamentos, preferencialmente em vertentes côncavo-convergentes e convexo-convergentes, modificando a sua forma ao longo do tempo.

A partir das informações métricas das voçorocas apresentadas, observa-se que os maiores valores dimensionais concentram-se nas formas Ramificadas e Irregular Mista, fato que denota relação principalmente às características de relevo, com base convexa da encosta e maior altimetria, resultando em maiores profundidades.

Entretanto, é importante observar que a modalidade de forma Ramificada apresenta maior diversidade em seu perímetro, dado que expressa variação em relação ao tamanho desse conjunto de voçorocas. De maneira menos expressiva, esse detalhe também acontece com as que apresentam a forma Irregular Mista e Irregular retangular. Esse detalhe permite inferir que essas modalidades têm afinidades em relação aos fatores da sua gênese e/ou até mesmo o próprio estágio de sua evolução.

Dessa forma, nota-se o agrupamento das seis formas de voçorocas de acordo com os dados métricos, ou seja, as modalidades Ramificada e Irregular Mista, entre as demais formas, são as que apresentam os maiores valores em área, perímetro, profundidade, comprimento e volume, além dos baixos valores de 
Índice de Circularidade. Já as formas Linear e Bulbiforme apresentam-se com os menores valores de área e volume, com valores de Índice de Circularidade intermediários. As formas Retangular e Irregular Re- tangular agrupam-se devido a valores intermediários de área e volume, mantendo um alto Índice de Circularidade, relacionado ao avançado estágio de evolução dessas formas de voçorocas.
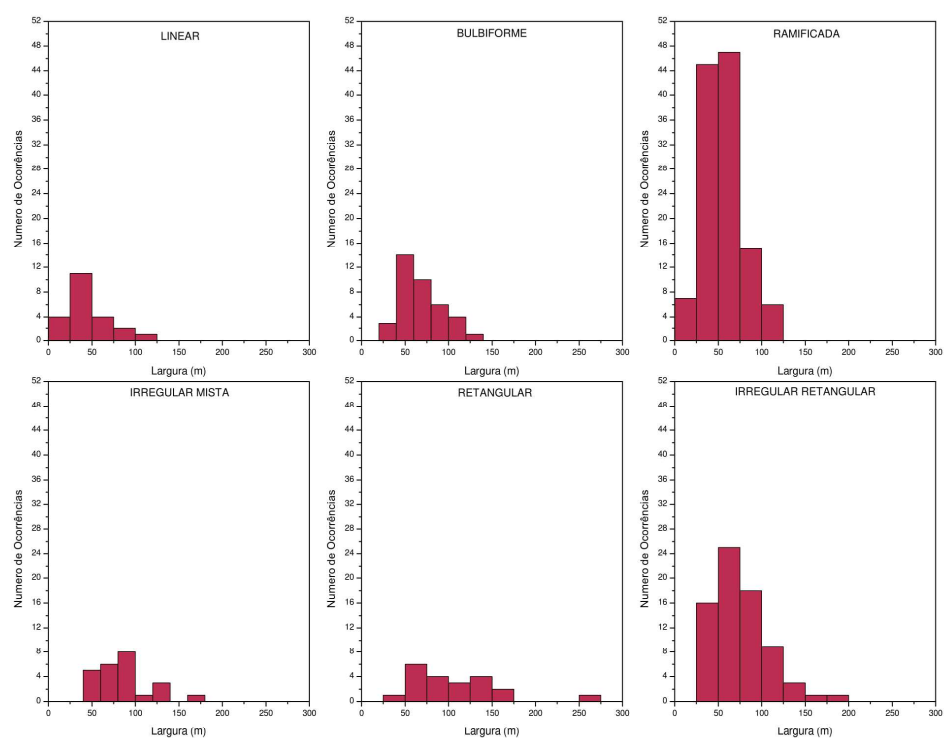

Figura 8 - Ocorrência de voçorocas em relação as suas modalidades versus Largura.

$\mathrm{Na}$ análise dos lineamentos estruturais, levou-se em consideração duas escalas de análise, sendo uma análise geral da área de estudo e outro para as voçorocas, para efeitos de comparação. Para a área de estudo, foram extraídos 4.089 lineamentos e, para as voçorocas, 6.572 lineamentos, ambos analisados por meio de estatística vetorial (NUM-
MER et al., 2013). Na área de estudo, a maior frequência dos lineamentos corresponde à Família de direção SE (azimute $140^{\circ}$ ), seguida das famílias de direções E-W, NE e N-S (Figura 9-A). Já nas voçorocas, predominaram as famílias de direções E-W e NE, cujo resultado pode ser visto no diagrama de rosetas da Figura 9-B.

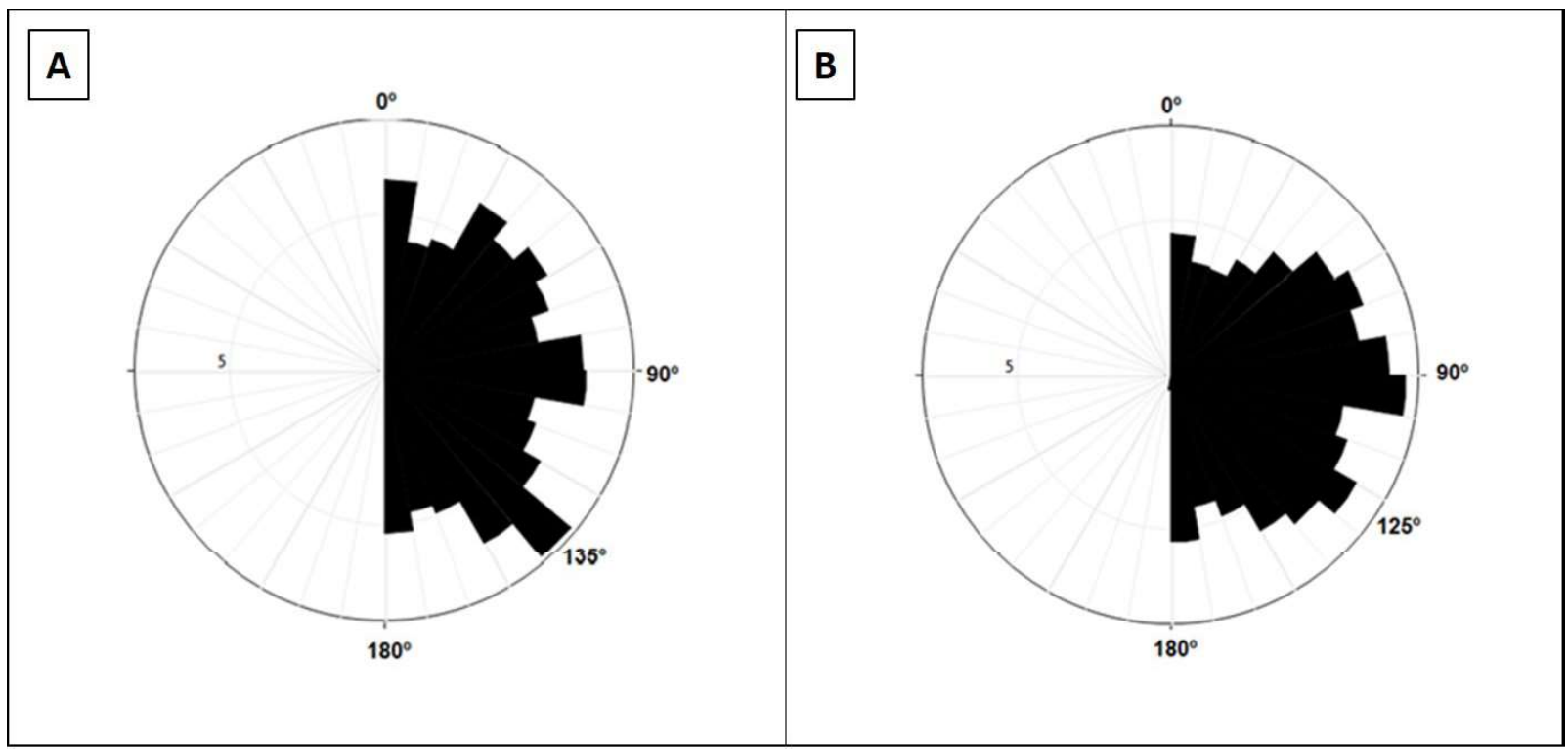

Figura 9 - Histograma circular de frequência dos lineamentos - (A) Área de estudo (4.089 medidas) e (B) Interior das voçorocas (6.572 medidas). 
A concentração dos lineamentos no quadrante E-W coincide com o comportamento estrutural regional da área de estudo, ou seja, percebe-se o predomínio dessa direção em todas as formas de voçorocas, o que significa a existência de uma forte influência dos arranjos regionais de fraturas ligadas aos principais sistemas de drenagens retilíneos e paralelos, conforme Asmus (1978), como o Rio Ibicuí, por exemplo.

Considerando a relação dos lineamentos com as formas das voçorocas, pode-se dizer que:

- A forma Linear apresenta direção preferencial NE3 e secundariamente E-W, o que se repete nas voçorocas com forma Bulbiforme, pelo fato de serem consideradas uma evolução da primeira.

- As formas Ramificada e Irregular Mista são as mais ativas e apresentam lineamentos de direções preferenciais E-W e N-S, bem como SSE e NE3, que formam conjugados em padrão retangular (associadas as principais direções de reativações).

- As formas Irregular Retangular e Retangular mostram algum estágio de estabilização com padrões de lineamentos E-W e SSE, formando conjugados retangulares como NE3 e SSE para a Irregular Retangular e E-W e N-S ou SSE e NE3 para a forma Retangular.

A partir desses dados, é possível afirmar que existe uma relação entre a presença de voçorocas e a distribuição dos lineamentos verificados em ambos os arranjos estruturais (área como um todo e voçorocas). A gênese e evolução (forma) dos processos erosivos por voçorocas estão associadas e/ou sofrem influência da tectônica frágil que se estabeleceu na região.

Com base nos trabalhos de campo e nos dados referentes ao conjunto de índices morfométricos, sugere-se um cenário de evolução do processo erosivo considerando as formas das voçorocas. As voçorocas iniciariam com uma concentração de fluxo d'água (voçoroca Linear) relacionado às estruturas geológicas de direção, preferencialmente NE e E-W, que poderia evoluir até chegar a Retangular, que seria o estágio mais avançado da evolução.

A forma Irregular Mista seria uma feição combinada levando em consideração o quadro evolutivo, pois ela mantém uma base linear, com abertura na média vertente e ramos no topo. Em alguns casos, os ramos podem apresentar características Bulbiformes. Essa classe poderia desenvolver-se para uma Irregular Retangular, onde estaria ligada principalmente a um aumento do seu índice de circularidade.

A forma Retangular seria um estágio avançado de desenvolvimento característico de estabilidade, entretanto poderia reativar e evoluir para as formas Irregular Retangular e Irregular Mista.

\section{Considerações Finais}

O presente trabalho desenvolveu uma análise das estruturas e dos índices morfométricos advindos das voçorocas presentes nas sub-bacias no município de Cacequi-RS, para classificar as suas diferentes formas. Embora a litologia da Formação Pirambóia possa variar, ela não foi considerada neste estudo como um parâmetro para a classificação das formas, tendo em vista o grande número de voçorocas identificadas (298) e a extensão da área, o que demandaria um trabalho de campo muito extenso.

Neste estudo, a interpretação da forma das voçorocas deu-se, primeiramente, por meio de uma análise visual de suas características em campo e em imagens de satélite. Posteriormente, foi realizada uma análise quantitativa que complementou a classificação das formas por meio dos indicadores morfométricos

Dessa forma, a relação qualitativa e quantitativa, incluindo a análise dos lineamentos, foram complementares entre si e indissociáveis para estabelecer-se os indicadores morfométricos que caracterizam cada uma das formas de voçorocas encontradas na área de estudo. Trabalhos como os de Bigarella (2003) e Vieira (2008) foram importantes para auxiliar na avaliação preliminar das formas das voçorocas, porém é preciso considerar as características específicas do local, onde os processos desenvolvem-se (tipos de litologia e estruturas geológicas, entre outros ), para, dessa maneira, adaptar outras categorizações às especificidades da área em que se encontram.

Os resultados de todos os procedimentos descritos forneceram subsídios para a fase de classificação das voçorocas, em que foi possível definir seis formas para a área de interesse, sendo elas: Linear, Bulbiforme, Ramificada, Irregular Mista, Retangular e Irregular Retangular. A relação entre a análise qualitativa e quantitativa das feições erosivas foi essencial na identificação das diferentes formas de voçorocas.

Foram identificadas, na área de pesquisa, 22 voçorocas Lineares, 38 Bulbiformes, 120 Ramificadas, 24 
Irregular Mistas, 21 Retangular e 73 Irregular Retangular, totalizando 298 incisões.

As voçorocas apresentam-se como grandes incisões, com volume médio erodido por feição em torno de $254.644 \mathrm{~m}^{3}$, ocupando $8 \%$ da área de pesquisa. As menores voçorocas concentram-se na Sub-bacia Sanga Areal da Limeira e as maiores, na Sanga da Vaca Velha e Arroio Areal Grande. Em termos métricos, a Sanga da Vaca Velha apresentou as maiores voçorocas em comprimento ( $838 \mathrm{~m}$ ) e o Arroio Areal Grande, a maior em largura média $(71 \mathrm{~m})$ e profundidade média de 3,5 $\mathrm{m}$, ambas bacias assemelham-se nas características métricas.

Ao analisar-se as formas das voçorocas, é possível agrupá-las em três conjuntos com aspectos similares entre si. Em um primeiro grupo, tem-se as formas Lineares e Bulbiformes, com menores valores de área, profundidade e volume. No segundo, estão as formas Ramificada e Irregular Mista que possuem as maiores áreas, perímetros, amplitudes altimétricas e profundidades. Já as formas Retangular e Irregular Retangular apresentam valores médios com relação à área, amplitude altimétrica e volume.

Os índices morfométricos e os trabalhos de campo foram utilizados para sugerir um cenário de evolução do processo erosivo com base nas formas das voçorocas. $\mathrm{O}$ processo de voçorocamento iniciaria pela forma Linear, até chegar a Retangular, considerada o estágio mais avançado. A Forma Irregular Mista poderia resultar da evolução de uma Linear ou Bulbiforme e evoluir para uma Irregular Retangular com o aumento do índice de Circularidade. Da mesma maneira, a forma Retangular, com características de estabilidade, poderia reativar e evoluir para as formas Irregular Retangular e Irregular Mista.

A análise dos lineamentos contribuiu para a compreensão da rede de drenagem local e regional e da orientação das voçorocas. As direções das incisões mapeadas mostram um controle estrutural com predominância na orientação E-W, coincidente com a direção do principal rio da região (rio Ibicuí). A associação dos lineamentos com os elementos morfológicos permite supor uma dinâmica geomorfológica da área com possível influência da neotectônica, o que deverá ser averiguado em estudos posteriores.

Vale ressaltar que a elaboração de um modelo evolutivo do processo erosivo, considerando as formas das voçorocas, requer maiores discussões e levantamentos de informações, voltadas, principalmente, ao conhecimento geológico.

\section{Agradecimentos}

Os autores agradecem à Coordenação de Aperfeiçoamento de Pessoal de Nível Superior (CAPES) pelo apoio financeiro ao longo do Doutorado Sanduíche no Exterior, edital PDSE 19/2016.

\section{Referências Bibliográficas}

ASMUS, H. E. Hipóteses sobre a origem dos sistemas de zonas de fraturas oceânicas/alinhamentos continentais que ocorrem nas regiões Sudeste e Sul do Brasil. Série Projeto REMAC, v. 4, 1978.

BARBOSA, M. E. F.; FURRIER, M. Caracterização geomorfológica com apoio de índices morfométricos: o estudo de caso da bacia do rio Guruji. Cadernos do Logepa, v. 6, n. 1, p. 1-24, jan./jun. 2011.

BIGARELLA, J. J.; MAZUCHOWSKI, J. Z. Visão integrada da problemática da erosão. In: Simpósio Nacional de Controle da Erosão, 3., 1985, Maringá. Anais... Maringá: ABGE-ADEA. 1985. 332p.

BISWAS, S. S. Analysis of GIS Based Morphometric Parameters and Hydrological Changes in Parbati River Basin, Himachal Pradesh, India. Journal of Geography \& Natural Disasters, v, 6, n. 2, 2016.

CABRAL, I. L. L. Depressões interfluviais e voçorocas articuladas à rede de drenagem: o exemplo das bacias dos rios Ibicuizinho, Areal do paredão, Cacequi, Santa Maria e Ibicuí. Tese (Doutorado em Geografia). Faculdade de Filosofia, Letras e Ciências Humanas, Universidade de São Paulo, São Paulo. 2004. 187p.

CASTRO, S. B.; CARVALHO, T. M. Análise morfométrica e geomorfologia da bacia hidrográfica do rio Turvo - GO, através de técnicas de sensoriamento remoto e geoprocessamento. Scientia Plena, v. 5, 2009.

CHRISTOFOLETTI, A. Análise morfométrica de bacias hidrográficas. Notícia Geomorfológica, v. 18, n. 9, p.35-64, 1969.

CHRISTOFOLETTI, A. Geomorfologia. 2 ed. São Paulo: Editora Blucher, 2011. 188p.

CUNHA, C. M. L.; PINTON, L. G. A cartografia do relevo como 
subsídio para a análise morfogenética de setor cuestiforme. Mercator, v. 12, n. 27, p. 149-158, 2013.

FILOSOFOV, V. P. Brief Guide to Morphometric Methods in Search of Tectonic Features. Saratov: Saratov University Publishing House, 1960.

FERNANDES, J. F. C. Modelação de Processos Erosivos no Alto Douro Vinhateiro: o caso de estudo da Quinta de S. Luiz. Dissertação (Mestrado em Geografia). Universidade do Porto, Porto. 2014. 135p.

HASENACK, H.; WEBER, E. Base cartográfica vetorial contínua do Rio Grande do Sul - escala 1:50.000. UFRGS Centro de Ecologia. 1 DVD-ROM. (Série Geoprocessamento n.3). ISBN 978-85-63483-00-5 (livreto) e ISBN 978-85-6384301-2 (DVD). Porto Alegre, 2010.

JACQUES, P. D.; SALVADOR, E. D.; MACHADO, R.; GROHMANN, C. H.; NUMMER, A. V. Application of morphometry in neotectonic studies at the eastern edge of the Paraná Basin, Santa Catarina State, Brazil. Geomorphology, v. 213, p. 13-23, 2014

MARCHIORI, J. N. C. Vegetação e areais no sudoeste RioGrandense. Ciência \& Ambiente, v. 11, p. 81-92, 1995.

NUMMER, A. V.; PIRES, C. A. F.; STRIEDER, A. J. Uso de estatística vetorial para análise de lineamentos da Bacia do rio Três Forquilhas, Nordeste do rio Grande do Sul. Revista Brasileira de Estatística, v. 74, n. 239, p. 21-42, 2013.

PÁNEK, T. The use morphometric parameters in tectonic geomorphology (on the example of the Western Beskydy Mts). Acta Universitatis Carolina e Geographica, n. 1, p. 111-126, 2004.

ROBAINA, L. E. S.; TRENTIN, R. Degradação dos solos: Problema ambiental no sudoeste gaúcho. Interface, v. 1, n. 1, p. 29-41, 2004.

ROBAINA, L. E. S.; NETO, S. F.; PAULA, P. M.; PEREIRA, V. P. Processo Erosivo Acelerado no RS: Voçorocamento no Município de Cacequi. Revista de Geografia Teorética, v. 27, n. 2, p. $109-120,2002$.
ROSS, J. L. S. Geomorfologia: Ambiente e Planejamento. São Paulo: Contexto, 1996.

ROSSATO, M. S. Os climas do Rio Grande do Sul: variabilidade, tendências e tipologia. Tese (Doutorado em Geografia). Universidade Federal do Rio Grande do Sul, Porto Alegre. 2011. 240p

STRIEDER, A. J.; AMARO, V. E. Structural patterns removed from remotely sensed lineaments. Egatea - Revista da Escola de Engenharia, v. 25, n. 4, p. 109-117, 1997.

SUERTEGARAY, D. M. A.; GUASSELLI, L. A.; VERDUM, R. Atlas de Arenização: Sudoeste do Rio Grande do Sul. 1 ed. Porto Alegre: Secretaria da Coordenação e Planejamento, 2001.

TRENTIN, R.; ROBAINA. L. E. S.; SCCOTI, A. A. V. Determinação dos litótipos aflorantes na bacia hidrográfica do rio Ibicuí, RS. Revista Geografia Ensino \& Pesquisa, v. 19, n. 2, p. 75-95, 2015.

VIEIRA, A. F. G. Desenvolvimento e distribuição de voçorocas em Manaus (AM): Principais fatores controladores e Impactos urbano-ambientais. Tese (Doutorado em Geografia). Universidade Federal de Santa Catarina, Florianópolis. 2008. 310 p.

WILSON, J. S.; CHANDRASEKAR, J. N.; MAGESH, N. S. Morphometric Analysis of Major Sub-Watersheds in Aiyar \& Karai Pottanar Basin, Central Tamil Nadu, India Using Remote Sensing \& GIS Techniques. Bonfring International Journal of Industrial Engineering and Management Science, v. 2, n. 1, 2012.

ZAIDAN, R. T.; XAVIER DASILVA, J.(2010). Geoprocessamento aplicado ao zoneamento de áreas com necessidade de proteção: O caso do Parque Estadual do Ibitipoca - MG. In: XAVIER DA SILVA, J.; ZAIDAN, R. T. (orgs). Geoprocessamento \& Análise Ambiental. Editora Bertrand Brasil, Rio de Janeiro: p. 31-65.

ZALÁN, P. V.; WOFF, S.; CONCEIÇÃO, J.C.J.; MARQUES, A.; ASTOLFI, M. A.M.; VIEIRA, I.S.; APPI, V.T.; ZANOTTO, O. A. (1990) Bacia do Paraná. In: RAJA CABAGLIA, G.P.; MILANI, E. J. (eds.). Origem e evolução das Bacias Sedimentares. Petrobrás, Rio de Janeiro: p.135-168. 